\title{
Creating COVID-19 Health Protocol Communication Materials in Filipino: A Translation Study
}

\section{Claudine Mariano Alhambra Eva Navarro}

St. Paul University Manila, Philippines

calhambra@spumanila.edu.ph

DOI: http://doi.org/ 10.36892/ijlls.v3i1.494

\begin{tabular}{ll}
$\begin{array}{l}\text { Received: } \\
\text { 01/01/2021 }\end{array}$ & $\begin{array}{l}\text { Amidst Covid-19, the World Health Organization (WHO) conducted an online } \\
\text { course in multiple languages during the first quarter of 2020, as part of their }\end{array}$ \\
\hline Accepted: & global response to the emergency (Utunen, et al., 2020). Although English is \\
03/03/2021 & one of the official languages in the Philippines, the country is multilingual, \\
& and Filipino is mostly spoken and more widely understood. This translation \\
& study aimed to create Covid-19 health protocol communication materials in \\
Keywords: & Filipino to cater to a general audience. Adopting the Interpretive Theory of \\
translation study, & Translation (ITT) by Danica Seleskovitch and the sixth element \\
COVID-19, health & (understandable) of the WHO Strategic Communications Framework for \\
protocols, & Effective Communication (2017), the study developed the Translating and \\
communication & Creating Communications Material Framework to guide the research process. \\
materials, Filipino & With this, the study was involved in synthesizing gathered information on \\
& Covid-19 health protocols which are in the source language, English. The \\
& translation itself involved deverbalizing and transcoding, where making sense \\
& of the information was done before they were completely translated to the \\
target language, Filipino. Since the main aim is to communicate \\
understandable information, the communication materials are in infographics \\
form. Some English terms were also retained as they are easier to \\
comprehend by the general audience who are households in selected \\
communities.
\end{tabular}

\section{INTRODUCTION}

Due to the Covid-19 pandemic, the year 2020 was also a year of cautious compliance to health protocols. The first two quarters of the year were critical as the whole globe was careful about the transmission of the virus. To avoid or minimize the spread of Covid-19, it is more critical that people are properly informed, and that there is access to credible and understandable information. According to the World Health Organization (WHO) Strategic Communications Framework for Effective Communication (2017), the six principles for effective communication are the following: (1) accessible, (2) actionable, (3) credible and trusted, (4) relevant, (5) timely, and (6) understandable. It is imperative that these principles are met especially during a pandemic. Information about the Covid-19 was both overwhelming and alarming. It was overwhelming because there were different theories on how the virus was transmitted, and alarming because it was scary for many, yet they did not know which information to believe. The term "infodemic" is used to describe this 
phenomenon, when "unreliable information spreads far and wide" (Zimmer, 2020). According to Zimmer (2020), infodemic, which is a combination of the words information and epidemic, was coined in 2003 by political scientist David J. Rothkopf in his Washington Post opinion piece discussing SARS; WHO also accepted the said term to describe the spread of false and confusing information during the 2020 pandemic. In the Philippines, media organizations broadcast a series of media literacy webinars focused on countering infodemic and disinformation (or in media terms, fake news).

In a time when information is readily available, the challenge lies not on the accessibility of information but on its credibility. Moreover, information seem to be dynamic, especially with the Covid-19 health protocols. For example, in the beginning of 2020, when there was still a relatively manageable spread of the virus and a low supply of face masks, people were not advised to necessarily wear face masks except for those who have the flu or experiencing flu-like symptoms. However, as the virus progressed, it became imperative that everyone wear face masks and observe social distancing. Hence, information must be timely and relevant. It is crucial that information come from reliable sources and that they have scientific bases. In April 2020, United States President Donald Trump suggested injecting disinfectant to the human body and exposure to ultraviolet light may kill the virus (Reality Check Team BBC News, 2020). In the local context, Philippine President Rodrigo Duterte in July also insisted disinfecting face masks with petrol (Reuters Staff, 2020). Both were quick to be dismissed by health experts; still, there is danger to these remarks as some may take these seriously knowing that these came from national political leaders. This study is concerned in delivering effective communication to the public by satisfying all the elements of the WHO Strategic Communications Framework. It is specifically centered on the sixtth element indicating that communication needs to be understandable. Health-related information for non-medical personnel may be technical due to the use of jargons. According to WHO (2017), communicators can assure that information is understandable with the following guideline:

- using clear and plain language to explain global health issues and guidance; - telling stories with a human dimension to make the issues real to those at work;

- incorporating visual components that show and enhance WHO content; and - communicating in multiple languages, including the six official languages (and more as necessary)

The six official languages of WHO are Arabic, Chinese, English, French, Russian and Spanish. The organization is active in promoting multilingualism through publishing translations of their information materials (WHO, 2020). Amidst COVID-19, WHO conducted an online course in multiple languages during the first quarter of 2020, as part of their global response to the emergency (Utunen, et al., 2020). Although English is one of the official languages in the Philippines, the country is multilingual, and Filipino is mostly spoken and more widely understood. Hence, the significance of this study lies in the essence of translating information in the local or national language to ensure effective and understandable communication. 
A study in 2012 found out that knowledge translation is lacking in the health services research organizations in the United States, which means that their findings rarely reach end users such as policymakers and the general public (Opsahl, 2012). One of the recommendations was to increase knowledge translation activities, which also require a cultural shift and collaboration with the community. In relation to the current study, COVID19 health protocols need to be translated in Filipino for the understanding of the general public. In a multicultural and multilingual context, such as the US and the Philippines, language barriers can pose COVID-19 problems. The Hispanic Center of Western Michigan said that their area experienced delay of information in communities where Spanish is the main language used. As a result, the lack of translation and interpretation of information in the area added to the COVID-19 problem (Wynder, 2020). In response to the said issue, nonEnglish speaking countries demonstrated efforts in information dissemination. China recognized the important role of translation in an emergency response in terms of accessing information. A study in Wuhan China looked into the practices of volunteer translators during the early stages of the pandemic. Instead of disseminating COVID-19 health protocols, their work was focused on facilitating medical supplies donation between Wuhan and the world (Zhang \& Wu, 2020). The study also emphasized the need for multilingual resources for disaster relief and "multilingual logistics in national emergency preparation, response and recovery plans.” In Italy, a more sophisticated approach to share COVID-19-related medical investigations through a new Italian de-identification data set was developed in a study. The objective of the computer software was to transfer knowledge between languages, specifically related to Covid-19 clinical records. Through this approach, they were able to deidentify or keep the privacy of personal identities in medical records from Italian to English (Catelli, R. et al. 2020). A study in South Korea evaluated Korean-language YouTube videos with Covid-19 content produced by the government, news agencies and private users. According to the study, the majority of the content were related to the transmission of the virus and precautionary measures. The evaluation also revealed misleading information from some of the videos; nonetheless, the authors recognize that one of the reasons for the rapid decline of the COVID-19 cases in the country was the increased public awareness through the digital platform, YouTube.

Language and linguistic studies prove to be an essential in a global emergency, such as a pandemic. Pragmatic discourses and semantic analysis relating to COVID-19 in different languages were also studied to reflect different perspectives about the virus (Augustine \& Prazmo, 2020; Mesthrie, 2020; Olimat, 2020). During the language month or Buwan ng Wika in the Philippines in August 2020, the theme was centered on the Philippine languages as weapon in fighting COVID-19, as information is weapon and knowledge is power. In the country, those who need the information the most are indigenous communities where information is not translated and explained to them. This is where linguists and language experts come in. This paper is in response to the lack of linguistic studies in the Philippines relating to the dissemination of COVID-19 information. This translation study aimed to create COVID-19 health protocols in Filipino. Although the Department of Health (DOH) already have Covid-19 health protocols in Filipino, the purpose of this study is to demonstrate the translation process to ensure the accuracy of information guided by the 
WHO Strategic Communications Framework for Effective Communication. This is also an effort to aid the government in disseminating information to communities where most residents cannot afford internet subscription. Specifically, this study's objectives were: (1) to gather the health protocols that need to be communicated to Filipino-speaking communities; (2) translate the English information to a localized and understandable form; and (3) create the communication materials.

\section{METHODOLOGY}

This research is part of a bigger collaborative project between St. Paul University (SPU) Manila and St. Charles Borromeo Philippine Medical Mission (SCBPMM) during the academic year 2020-2021. SCBPMM is a non-government organization especially dedicated to promote the right of poor Filipinos to access health care, and empower them through education, so that they become "responsible and productive members of society" (SCB Philippine Medical Mission, 2019). The role of SPU Manila in the SCBPMM Project is to produce communication materials relating to Covid-19 health protocols for the selected communities, and conduct surveys and trainings. This study is particularly focused only on the project's first phase. The first phase of the project, which was executed from October to December 2020, was to gather Covid-19 health protocols, translate them into Filipino, and then create the communication materials in the form of infographics. SPU Manila's Community Development Center (CDC) and the other colleges worked together in the first phase. The College of Nursing and Health Sciences (CNAHS) were assigned to gather trusted and credible Covid-19 health protocols mostly from WHO; information that were gathered are in English. Meanwhile, the College of Arts, Sciences and Education (CASE) were involved in the translation of health protocols into Filipino and the creation of the communication materials into infographics. CASE was also involved in the gathering and creation of mental health protocols amidst the Covid-19 pandemic. However, the group, who were Psychology Majors, assigned to gather and create these communication materials worked on the translation on their own, so this part was excluded in this translation study. Nonetheless, the translation made was still checked before the compiling and finalizing the communication materials. Another limitation of this study is that the researchers were not involved in the selection of particular communities who will receive the communication materials. What was clarified was that the communication materials will be distributed to barangay officials and households in the Manila City area, so the basis of audience or readers is general. The evaluation and revision process of the infographics are also not part of this study.

As basis for the operational framework, the researchers looked into two theoretical frameworks, one of which has been mentioned earlier, that is, WHO's Strategic Communications Framework for Effective Communication. However, since this study is mainly focused on the translation, only the sixth element, understandable, will be adopted in the operational framework. The other theory is related to the equivalence principle of Translation Studies, specifically the Interpretive Theory of Translation (ITT) by Danica Seleskovitch developed in the 1970s (Benjamins, 2010). This theory was selected because it 
uses a communicative approach. In this perspective, it is meaning and not language that is being translated; hence, language is just a "vehicle for the message," and may be an "obstacle to understanding" (Cultures Connection, 2020). This theory is founded on the theory of sense, which recognizes deverbalizing as an important step in the process. To deverbalize means to interpret the meaning of the text or discourse from the source language to the target language through the interpreter's cognitive supplement or background knowledge (Kang, 2013). Jungwha (2003) used the term "cognitive complement" in his discussion of the ITT. Here, he argues that "knowledge of the world is language independent.," which means the interpretive process tries to make sense of the message or content, rather than simply transcoding a foreign text to a local one. This is why this theory is not very much concerned about the symbols and codes of the language but rather how the meaning must be comprehended by the translator to make it more meaningful to the recipients of the message. Below is the Interpreting Triangular Model by Seleskovitch (1984, as cited by Kang, 2013).

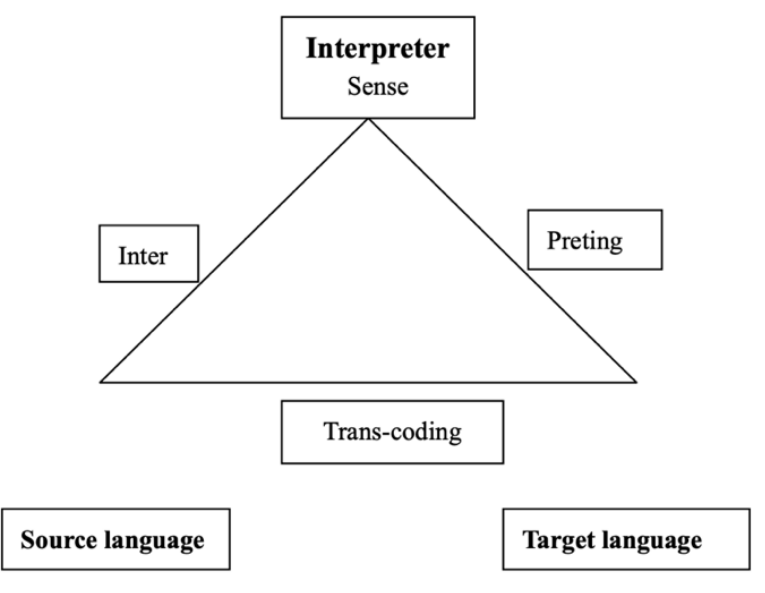

Figure 1. Interpreting Triangular Model by Seleskovitch (1984, as cited by Kang, 2013)

Adopting the two theories, the researchers developed a framework to guide the process of this study.

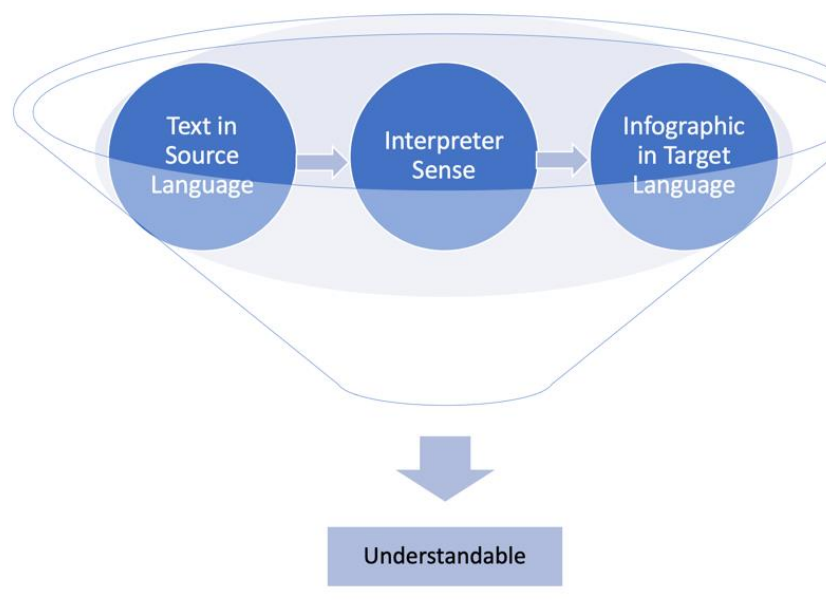

Figure 2. Translating and Creating Communication Materials Framework 
Figure 2 shows the operational framework of the study, which guided the process to develop Covid-19 health protocol communication materials in Filipino. The process starts with the original text in the source language, in this case, English. Although it is not shown in this study, the gathering and synthesizing of credible information for the communication materials went through a rigorous process by itself, as there were overwhelming sources. This pre-process of checking, validating, and revising of information also satisfies the first five elements of WHO's Strategic Communications Framework for Effective Communication. The synthesized information was used as basis in the translation process following Seleskovitch's interpreter sense. The output are actual communication materials in infographic form, which the researchers did not create themselves. The three steps are put in a funnel-like figure, where the expected outcome needs to be understandable, as set by the standards of the WHO Effective Communication Framework. It dictates that the infographic in the target language should: use clear and plain language to explain the health protocols, tell stories if necessary, incorporate visual components especially for instructions, and communicate in the local language, Filipino.

\section{RESULTS AND DISCUSSION}

As guided by the St. Paul University Manila's Faculty in the College of Nursing, information for four main topics were researched as basis for the Covid-19 health protocols communication materials. As mentioned in the Methodology of this study, information presented have been checked to assure that they are accessible, actionable, credible and trusted, relevant, and timely; these information were checked to satisfy the first five elements of WHO's Strategic Communications Framework for Effective Communication. The four topics are: (1) information about the virus, (2) contact tracing, (3) role of barangay officials, and (4) self-care management. Presented below are the synthesized information for each topic.

\section{Text in Source Language}

Topic 1. Information about the Virus

There are 2 types of microbes/microorganisms and a virus is one of these (the other one being a bacteria). Influenza or flu is a type of virus that causes sickness in the upper respiratory tract and it usually takes 5-7 days to spread to another host after symptoms of fever, cough, cold or sore throat. People who get infected can spread it to others 2 to 3 days before symptoms start and are most contagious 1 to 2 days before they feel sick.

Influenza is contagious and can affect both humans and other animals alike. Flu is caused by an infection called influenza virus. It is caused by various types of influenza viral strains. Three types of influenza viruses are recognized: A, B, and C. Type A are more common. Influenza viruses are continuously changing, thus the need for annual flu vaccinations. Occasionally, influenza from animals can infect humans and these infections can manifest in a broad range of clinical symptoms from mild disease to death. If one's immune system is strong, then it will do its job perfectly to fight off microbes such s viruses and avoid further complications.

Influenza viruses can infect the nose, throat, and lungs of an individual, and these viruses spread with cough, sneeze, or just by merely talking. If you send droplets with the virus into the air, and potentially into the mouths or noses of people nearby, then the chances of spreading the virus are higher. The virus enters the body 
through either the oral cavity or the nose cavity, and then it infects the respiratory tract, paranasal sinuses, the throat, the lungs, and even the middle ear. It can also affect the air passages which can cause difficulty in breathing or Fast breathing due to blockage or mucus build up along the air passage that causes the patient to gasp for air. Due to foreign particles or mucus development in the lungs and throat, this causes the patient to cough. Coughing is a way to get rid of any foreign particles and irritants in the respiratory system. This could also cause pain in the patient's chest. To ease any chest discomfort, drinking warm fluids may help.

Influenza is most contagious in the first 3-4 days after their illness begins. Some otherwise healthy adults may be able to infect others beginning 1 day before symptoms develop and up to 5 to 7 days after becoming sick. On the other hand, in COVID 19 - it is possible for people to spread the virus for about 2 days before experiencing signs and symptoms and remain contagious for at least 10 days after signs and symptoms first appeared. If someone is asymptomatic or their symptoms go away, it is possible to remain contagious for at least 10 days after testing positive for COVID 19.

Anyone can get affected with flu viruses, even the healthiest of people but there are people who are at higher risk of developing serious flu-related complications if they get infected with flu viruses. This includes people 65 years and older, people of any age with certain chronic conditions such as asthma, diabetes, or heart disease, pregnant women and children younger than 5 years, but especially those younger than 2 years old.

\title{
HOW DOES VIRUS DEVELOP IN THE HUMAN BODY?
}

- SARS-CoV-2 attaches to the host cell by binding its $\mathrm{S}$ protein to the receptor protein, angiotensinconverting enzyme 2 (ACE2).

- ACE2 is expressed by epithelial cells of the intestine, kidney, blood vessels, and, most abundantly, in type II alveolar cells of the lungs.

- The human enzyme transmembrane protease, serine 2 (TMPRSS2), is also used by the virus for S protein priming and to aid in membrane fusion.

- The virus then enters the host cell via endocytosis. (cellular process in which substances are brought into the cell)

Signs \& Symptoms:

\section{Children}

Difficulty breathing or Fast breathing

Bluish lips or face

Fever with rash

Pain in the chest

Severe muscle pain

Unalert

Dehydration and loss of appetite

Fever or cough improves but

returns and becomes worse

\section{Adults}

Difficulty breathing or Shortness of breath

Dizziness or confusion

Pain in the chest or abdomen

Muscle pain and body weakness

Inability to urinate

Fever or cough improves but

returns and becomes worse

The information about the virus is explained by comparing Covid-19 to the common flu, in terms of the type of virus, symptoms, people who are at risk, and the difference in symptoms between children and adults.

\author{
Topic 2. Contact Tracing \\ BHERT (Barangay Health Emergency Response Team) \\ Shall focus on active case finding contact tracing by: \\ 1. Ensure monitoring throughout the duration of isolation \& quarantine \\ 2. Facilitate home care and basic needs \\ 3. The BHERT shall update all contacts' Signs and Symptoms Log Forms daily. \\ All BHERTs shall: \\ 1. Accomplish a Case Identification Form (CIF) \\ 2. Submit timely and accurate Individual Signs and Symptoms Log Forms to the P/C/MESU \\ 3. Daily report shall be forwarded to the Municipality/City Epidemiology and Surveillance
}


Units (MESU/CESU) which in turn are forwarded to the Provincial Epidemiology and Surveillance Units (PESU)

Contact Tracing Procedure for BHERT:

1. Secure on-hand, with a copy of RT-PCR test indicating that the patient is positive with COVID-19.

2. Request the patient to disclose all people with immediate contacts at least 2 days before the presence of symptoms.

3. Instruct to make 14 consecutive days of quarantine and self-monitoring - check body temperature, monitor if you experience symptoms like fever, cough, difficulty in breathing - twice a day.

4. Visit or call the patient every morning and afternoon to be updated regarding his/her health condition.

5. Record all the collated data from the standard monitoring log sheet for COVID-19.

6. Assist a Nurse or any trained personnel in doing the case investigation form (DOH standard form).

7. Report to the places where the patient and its immediate contact went so that they can be notified.

8. A COVID-19 positive patient's immediate contacts that experienced symptoms must undergo swab testing through consulting with their respective health centers.

PAALALA

- BHW and BHERT must conduct routine community visits / accepts information for possible COVID-19 patients

- All individuals experiencing untoward symptoms shall be coordinated promptly by the BHC and BHERT

- All suspected and probable patients are monitored under the Barangay Health Center (BHC). Document the common exposures and type of contact with the confirmed or probable case for any contact wh become infected with COVID-19

- Create a line list, including demographic information and geographic information at barangay and sitio levels, date of first and last exposure or date of contact with the confirmed or probable case, and, for symptomatic close contacts, date of onset of fever, respiratory symptoms, or other significant signs and symptoms.

- All of these will be reported to the Provincial/Municipal/City Epidemiology Surveillance Unit.

Confirmed COVID-19 cases are transferred and being monitored by the Provincial/Municipal/City Epidemiology Surveillance Unit.

CONFIRMED COVID-19 CASES

Identification and assessment of close contacts

Contact Tracing shall prioritize listing of the following close contacts:

1. Health workers who attended to the confirmed COVID-19

2. Individuals who lived with the confirmed COVID-19 case

3. Individuals who worked with the confirmed case

4. Vulnerable populations an identified in the demographic vulnerabilities tool

Tips for Early Contact Tracing in the Community

- Early and effective contact tracing is critical in controlling the spread of COVID-19 in the community.

- Encourage open and accessible communication channels with the community and health officials. (Ensure the community has the current contact numbers of barangay, health center, and 24/7 Covid-19 hotlines).

- All symptomatic patients should practice self-isolation immediately and contact the health officials in their Barangay.

- Before obtaining the results of the RT-PCR test, instruct the patient to compile a list of all contacts they have made 2 days prior to onset of symptoms.

- Reassure patients full confidentiality with regards to the contacts and to encourage honesty.

- Have a proactive and immediate approach to contact tracing.

ASYMPTOMATIC

NON-HEALTH WORKER

- Undergo 14-day strict home quarantine

- Monitor for development of sign or symptom until end of quarantine

- NO laboratory confirmatory testing

HEALTH WORKER WITH LOW RISK EXPOSURE 
- May report to work but shall undergo self-reporting for the next 14 days

- NO laboratory confirmatory testing

HEALTH WORKER WITH LOW RISK EXPOSURE

- Undergo 14-day strict home quarantine

- Monitor for development of sign or symptom until end of quarantine

- Undergo laboratory confirmatory testing

SYMPTOMATIC

FIT SUSPECT COVID-19 CASE DEFINITION

- Health facility isolation

- Undergo laboratory confirmatory testing

DID NOT FIT SUSPECT COVID-19 CASE DEFINITION

- Undergo 14-day strict home quarantine

- Monitor for development of sign or symptom until end of quarantine

- NO laboratory confirmatory testing

SUSPECT (DULOT): D - Diarrhea, U - Ubo, L - Lagnat $\left(38^{\circ} \mathrm{C}\right)$, O - Or T - Trangkaso

If you're suspecting you have COVID: TANDAAN ANG D U L O T

1. Naglakbay o nanirahan sa isang lugar na may ulat $\mathrm{ng}$ lokal na transmisyon ng sakit na COVID-19 sa loob ng 14 na araw bago nagsimula ang sintomas;

2. Nagkaroon ng close contact sa isang taong confirmed o probable na may COVID-19 sa loob ng 14 na araw bago nagsimula ang mga sintomas.

3. Mayroon kang lagnat o ubo o hirap sa paghinga

Kabilang sa isa sa mga nasa ibaba:

- Taong edad 60 taon at pataas;Taong mayroong iba pang sakit;

- Taong mayroong maselan na pagbubuntis; at,

- Mga health worker

Basic Case Reporting

Paano ginagawa ang basic case reporting?

What: Basic Case Reporting para sa mga COVID-19 positive

Why: To separate the ill or infected persons from others to prevent the spread of infection or contamination. At para makita kung gaano na kadami ang kaso ng COVID-19 sa isang lugar.

When: All BHERTs shall submit daily monitoring data of contacts to the P/C/MESUs, who shall submit to the RESU and EB by 10:00 AM the following day. Hospitals shall submit status updates of admitted COVID-19 cases to the RESU. The RESU shall submit these updates daily to EB by 5:00 PM.

How: A ladderized information flow shall be observed, starting from LCTTs, to P/C/MESUs, to RESUs, and to EB. In the future electronic submission of contact tracing data shall be utilized to ensure timely submission and validation of data at all levels.

- Upon acknowledging a suspected COVID-19 case from all of the health facilities that conducted sample collection, testing, consultation and admission, $\mathrm{P} / \mathrm{C} / \mathrm{MESUs}$ will have access to the complete medical record and help facilitate the interview together with the relatives, caregivers and guardians.

- All suspect cases shall be advised to inform identified contacts of the possible exposure, advise them to practice self-quarantine and self-monitoring, report development or progression of signs and symptoms and update local government the laboratory status of suspect COVID-19 case and re-classify them, as needed.

- The local contact tracing teams are responsible for confirmed COVID-19 cases. Hence, they're also responsible to rigorously locate, identify the profile, assess all close contact, for testing and for isolation.

How will cases be validated?

1. All health facilities that conducted sample collection, testing, and/or admission of confirmed COVID-19 cases shall ensure that $\mathrm{P} / \mathrm{C} / \mathrm{MESU}$ s are provided access to the complete medical record of the confirmed COVID-19 case and shall help facilitate the interview of the confirmed COVID-19 cases, relatives, and/or guardians. 
The Epidemiology Bureau (EB) shall:

- Design recording and reporting systems and applications to ensure timely submission of complete and valid data.

The Department of Health (DOH)

- Within 24 hours of the data being submitted to the DOH, it is immediately validated and reported at once the following day.

Some of the information under Contact Tracing are already in Filipino, since one of the references are from the Philippine's health agency, DOH. The text defines what contact tracing by presenting the 5 W's and H: (1) What is contact tracing? (2) Why is it important? (3) Where and when should it be conducted? (4) Who needs to undergo contact tracing? and (5) How should it be conducted? Furthermore, the information reminds people people to take note of people they interact with, but maintain data privacy at the same time.

Topic 3. Role of Barangay Officials

Roles of Local Chief Executives:

Anti-Coronavirus Information Manager

- Protects information that must be private and regulates the flow of information within and among the public

Local Crisis Manager

- $\quad$ Establishes and equips B.H.E.R.T, prevents overpricing and hoarding of P.P.E, and supervises suspected persons

Environmental Health Manager

- Overlooks cleanliness, sanitation, and disinfection of common areas or public places

\section{B.H.E.R.T}

Barangay Health Emergency Response Team

- Main Role: Preparedness, Prevention, and Quick Response

- "Eyes and ears" of the government to make sure residents within barangay are accounted for and aware of Coronavirus

- Punong barangay (Barangay Chairman) should appoint B.H.E.R.T

- $\quad$ Each B.H.E.R.T should have the ff:

- Executive Officer;

- Barangay Tanod;

$\circ \quad$ and two Barangay Health Workers (one of which should either be a nurse or a midwife)

\section{Functions of B.H.E.R.T}

1. Conduct visits in the home of every arriving person from a Coronavirus affected country

2. List down person/s who are and were in contact with these arriving residents

3. Require arriving persons to monitor temperature twice daily and to watch out for other Coronavirus symptoms for 14 days

4. Maintain a distance of more than one (1) meter and always wear a mask in checking on these arriving residents 


\section{MAKIPAG-UGNAYAN SA B.H.E.R.T. NG INYONG BARANGAY}

- Walang sintomas;

- Nanggaling sa China at ibang restricted na bansa

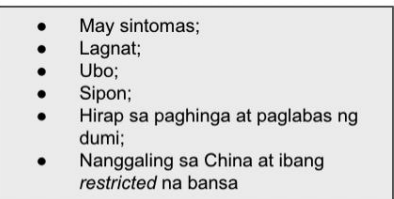

restricted na bansa
- May sintomas;

- Hindi nanggaling sa China o anumang bansa na may COVID-19
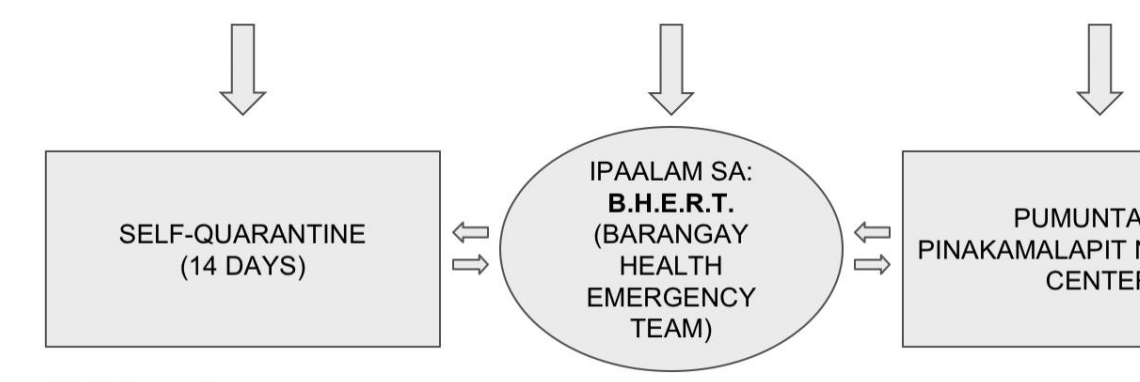

IPAALAM SA:

HEALTH

EMERGENCY

Manila Barangay Bureau

4. htip.//manila.gov.ph/2020/03/barangay-health-emergency-response-team-bhert/

Actions to take when symptoms are present (Infected)

1. Isolate and confine the arriving resident far away from the household members before transport to a DOH - designated coronavirus - referral center or hospital. Require to wear an N95 mask.

2. Place the rest of the household also under 14 - day home confinement.

3. Repeat the process for them, including contact tracing.

4. If no signs manifest, lift home confinement.

Actions to take in the absence of symptoms (Prevention)

- Conduct information campaign on Coronavirus and clean-up campaign for the whole barangay

- To facilitate reports on Coronavirus, set up a Barangay Information or Call Center

- Report to Punong Barangay (Barangay Chairman) actions taken per person

The intended audience for Topic 3 are not only the household but also the officers in the community or barangay officials. The information presents the general responsibilities of these officials, which is the implementation of the following: to protect the community, control the spread of the virus, and clean the surroundings. The community also needs to know where, to whom, and how to direct their concerns relating to Covid-19. Basically, the information presents the involvement of barangay officials in dealing with suspected Covid19 patients.

Topic 4. Self-care Management

\section{SELF-CARE MANAGEMENT}

\section{PAANO MAKAIIWAS/MAIIWASAN ANG IMPEKSYON?}

Ayon sa CDC, o Centers for Disease Control and Prevention, mayroong karaniwang pag-iingat para sa pagaalaga ng mga pasyente na maaaring magamit hindi lamang sa ospital. Ang pagkalat ng impeksyon ay maaring kontrolin sa pagsunod sa mga guidelines na ito para sa ikabubuti ng mga taga pag-alaga sa mga may sakit

\section{Physical Distancing}

Maintaining a physical distance of 2 meters ( 6 feet) away from other people. 


\section{Respiratory Etiquette}

Proper respiratory etiquette will help stop the germs from spreading and so, the respiratory disease.

2.1. Cover coughs or sneezes by using a tissue or cough or sneeze into your upper sleeve

2.2. Dispose or clean contaminated products immediately

2.3. Avoid spitting, if you must, spit into a tissue and dispose properly

\section{Hand Hygiene}

\section{Alternatives of Handwashing}

3.1. Alcohol - does not remove all types of bacteria and germs but removes a significant amount

3.2. Hand Sanitizer - can't be used when hands are filthy, greasy, or have touched harmful chemicals

3.3. Antiseptic Hand Wipes - more effective in cleaning surroundings than cleaning hands

\section{Key times to wash your hands:}

Before and After:

Preparing food

Caring for someone who is sick

Treating a cut or wound

After:

Coming from a public place

Using the toilet

Blowing your nose, coughing, and sneezing

Touching an animal, animal food or waste

\section{Misconceptions of Handwashing}

1. It doesn't matter how long I wash my hands as long as I use soap

2. Hand sanitizers can replace washing your hands with soap and water

3. The hotter the water you use for handwashing, the better

4. You don't have to dry your hands after washing them

5. Hand dryers are more hygienic than paper towels

4. Avoid touching the face with your hands especially if they're contaminated

\section{Proper Usage of FACEMASK}

1. Wash the hands before and after using facemask.

2. Check if there is any damage to the facemask. Make sure to have a securely fit mask.

3. The face mask must cover the nose, mouth, and chin. It is not intended to be worn under the nose, chin or any part of the body as it may be contaminated if exposed to surfaces.

4. Pinch metal strip to fit nose bridge.

5. When wearing facemasks, be sure to touch the straps/ear loops in wearing as well as removing it. 
6. Touching the face mask should be avoided.

7. Procedure/surgical masks are disposable. Proper disposal of facemasks should be observed.

8. Do not remove the mask to talk to someone or in the event of being near a person 1 meter away may expose an individual to unwanted airborne diseases.

9. If the mask is non-medical (cloth), make sure to wash it at least once a day with hot water and detergent to disinfect the facemask and prevent bacteria residing in the material.

10. Store reusable face masks in resealable plastic bags.

11. Do not share face masks nor let others get a hold of it to avoid having cross contaminations.

12. Discard your mask into an enclosed bin mask by holding onto the straps only.

\section{Temperature Taking}

How often should I take my temperature?

1. If you feel ill, it's likely to check your temperature.

2. If you decide to take medicine, follow a period of time (four to six hours interval) before taking another dosage.

3. However, if the first temperature check is very high. Recheck your temperature in a regular schedule (once or twice an hour).

\section{The 3 R's in the New Normal}

Reduce - Avoid impulsive buying of insignificant products

Reuse - Buy products that is QUALITY Bound

Recycle - Avoid recycling used products to avoid cross contamination

$K$ - Kaugalian lumayo ng dalawang metro

$A$ - Alamin kung gaano kalayo ang dalawang metro

$L$ - Lumabas lang kung kinakailangan

$A$ - Alalahanin na ang paghuhugas ng kamay ay dapat apatnapu't segundo

$T$ - Tandaan maghugas ng kamay gamit ang tubig at sabon

Lastly, Self-care Management are information on the dos and don'ts in order to avoid acquiring the virus. Misconceptions on hygiene practices are also presented and clarified. There were more information included in this section, but they had to be eliminated because they are not for the intended audience, rather they are specifically for health care workers, such as the use of PPEs (Personal Protective Equipment) and surgical gloves.

\section{Interpreter Sense}

Under the Interpreter Sense process are two steps namely, deverbalization and transcoding. The deverbalization part is the first attempt to make sense or meaning and comprehend the text in the source language. This process occurs in the consciousness of the translators themselves, so making sense here is solely for the translator and not yet for the recipient of the message. The strategy here was to further synthesize the information to ensure that only the necessary details are communicated to the intended audience. In this step, some part of the text may not necessarily be in the target language yet, and technical terms in English are still retained. The main purpose here is not only to comprehend but to gather just the essential information to be used in the infographics. The second step in the interpretation 
process is the transcoding where the information is in a more understandable form. With this, some of the English terminologies were also retained as Filipino in itself is an evolving language, which has adopted foreign ang indigenous languages. Here, it is important to realize that incorporating English terms in this context makes the translated text more comprehensible and communicable to the intended audience; after all, ITT is a communicative approach. According to Seleskovitch (1984, as cited by Kang, 2013), the translator's role is critical at this point as their knowledge in both languages and the subject or translation make the communication more effective. It is important to note as well that the translators, being bilingual (or multilingual) think in two (or more) languages. In this case, language may be an obstacle in (Cultures Connection, 2020). Hence, a two-step process was conducted to ensure equivalence in the translation.

Topic 1. Information about the Virus

\begin{tabular}{l}
\hline \multicolumn{1}{|c|}{ Deverbalization } \\
\hline Influenza vs. Covid-19 \\
Influenza A, B, C \\
- labis na nakakahawa 3-4 na araw matapos \\
magsimula ang sakit \\
-kalimitang lalabas ang sintomas matapos ang 1-4 oras \\
-droplet transmission
\end{tabular}

Covid-19

-Novel corona virus

-kalimitang lalabas ang sintomas 2-14 araw

-droplet transmission

Covid-19 Vulnerable Population

Child:

-blue lips stuporous

-fever with rash

-dehydrated, no appetite

-fever or cough that worsen

-chest pains, muscle ache

Adult:

-shortness of breath and chest pains

-body weakens and muscle pains

-inability to urinate

-abdominal upset

-initially retrieve cough but worsen as progresses

Once you experience signs related to the following, contact your barangay for immediate assistance.

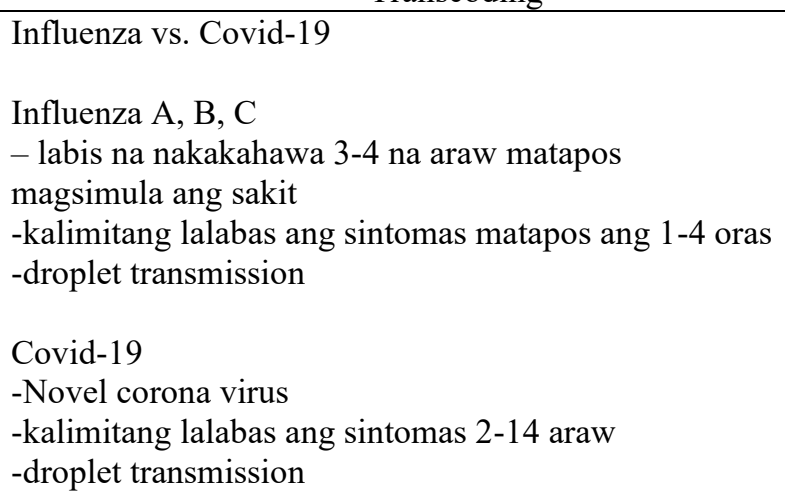

Covid-19

-Novel corona virus

-kalimitang lalabas ang sintomas 2-14 araw

-droplet transmission

Covid-19: Mga taong madaling kapitan ng virus

Bata:

-nangingtim na labi o mukha

-lagnat na may pamamantal / pangangati

-matinding lagnat o ubo

-dehydrated at walang ganang kumain

-masakit na dibdib

-pananakit ng kalamnan o katawan

Matanda:

-nahihirapang umhihi

-panghihina at pananakit ng katawan

-lumalalang ubo

-hirap sa paghinga

-patuloy na pananakit o paninikip ng dibdib

-pagsusuka o pagtatae

Kapag nararamdaman ang mga sintomas kaugnay ng mnga nabanggit, ipaalam agad sa barangay upang agad na maaksyunan. 


\begin{tabular}{|c|c|}
\hline Deverbalization & Transcoding \\
\hline $\begin{array}{l}\text { Let's flatten the curve } \\
\text { Contact tracing: } \\
\text { Ano? Paraan upang mahanap ang mga tao na maaring } \\
\text { na-infect ng Covid-19 virus } \\
\text { Saan? Pinagbibigay alam sa barangay na nasasakupan } \\
\text { Paano? Pinag-iingat na magkaroon ng karagdagang } \\
\text { nakakasalamuha dahil sa tyansa ng Covid-19 na sakit } \\
\text { Sino? } \\
\text {-close contact - individual who had interaction with } \\
\text { positive or probable covid patient; with face-to-face or } \\
\text { direct physical contact to covid patients; care without } \\
\text { PPE used } \\
\text {-confirmed case - mga indibidwal na nagpositibo sa } \\
\text { sakit at may mga pinakikita na sintomas } \\
\text {-probable covid - with inconclusive test result } \\
\text {-positve covid test by unaccredited testing labs } \\
\text {-died without any tetst done } \\
\text {-asymptomatic - mga indibidwal na positive sa swab } \\
\text { test ngunit walang ipinakikita na sintomas ng sakit } \\
\text { Paraan upang matandaan ang mga nakasalamuha } \\
\text {-ilista lahat ng mga nakasama ng mahigit } 15 \text { minuto } \\
\text { - basahin ang mga message sa telepno para maalala } \\
\text { ang mga nakasalamuha } \\
\text { Paalala (Data Privacy) - ibigay lamang ang } \\
\text { impormasyon sa tamang kinaukulan } \\
\text {-iawasan pagusapan at ipagsabi sa iba't ibang tao } \\
\text { kung mayroonf kakilala sa may sakit } \\
\text { Agad ipaalam ang mga kainakailangang impormasyon } \\
\text { upang matulungan mapabilis ang paghahanap sa mga } \\
\text { indibidwal na mayroong sakit. }\end{array}$ & 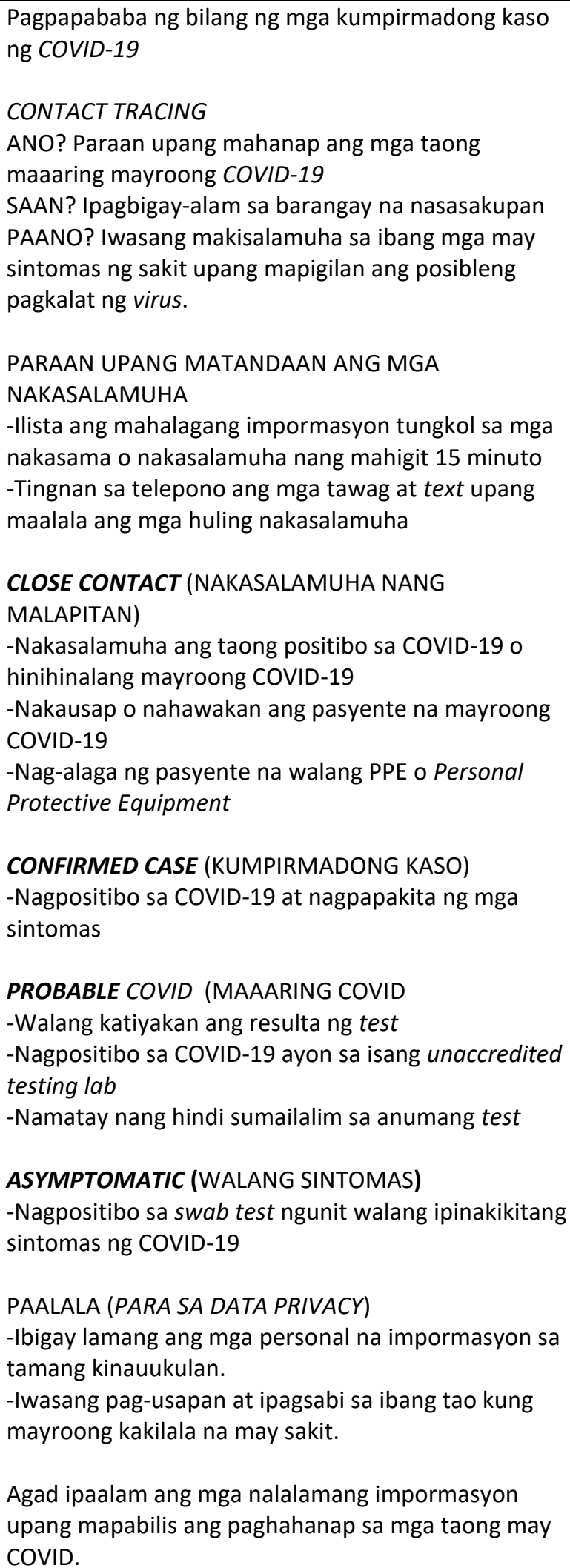 \\
\hline
\end{tabular}

Topic 3. Role of Barangay Officials 


\begin{tabular}{|c|c|}
\hline Deverbalization & Transcoding \\
\hline $\begin{array}{l}\text { Barangay Covi-19 Responders } \\
\text { Local Execitives } \\
\text {-ACIM - protect } \\
\text {-LCM - control } \\
\text {-EHM - clean } \\
\text { Function: } \\
\text { H - ome visit } \\
\text { A - way from each other } \\
\text { L - ist contacts } \\
\text { T - emp check, } 14 \text { days } \\
\text {-appointed staff } \\
\text {-Brgy worker } \\
\text {-medical prof } \\
\text { [Insert B.H.E.R.T process] } \\
\text { Prevention: } \\
\text {-information campaign } \\
\text {-reporting of case in brgy call center } \\
\text {-strict } 14 \text { days isolation } \\
\text {-constant use of N95 mask } \\
\text {-review contact list } \\
\text { If no observable signs seen to an isolated individual in } \\
\text { 14 days, home quarantine may be lifted }\end{array}$ & 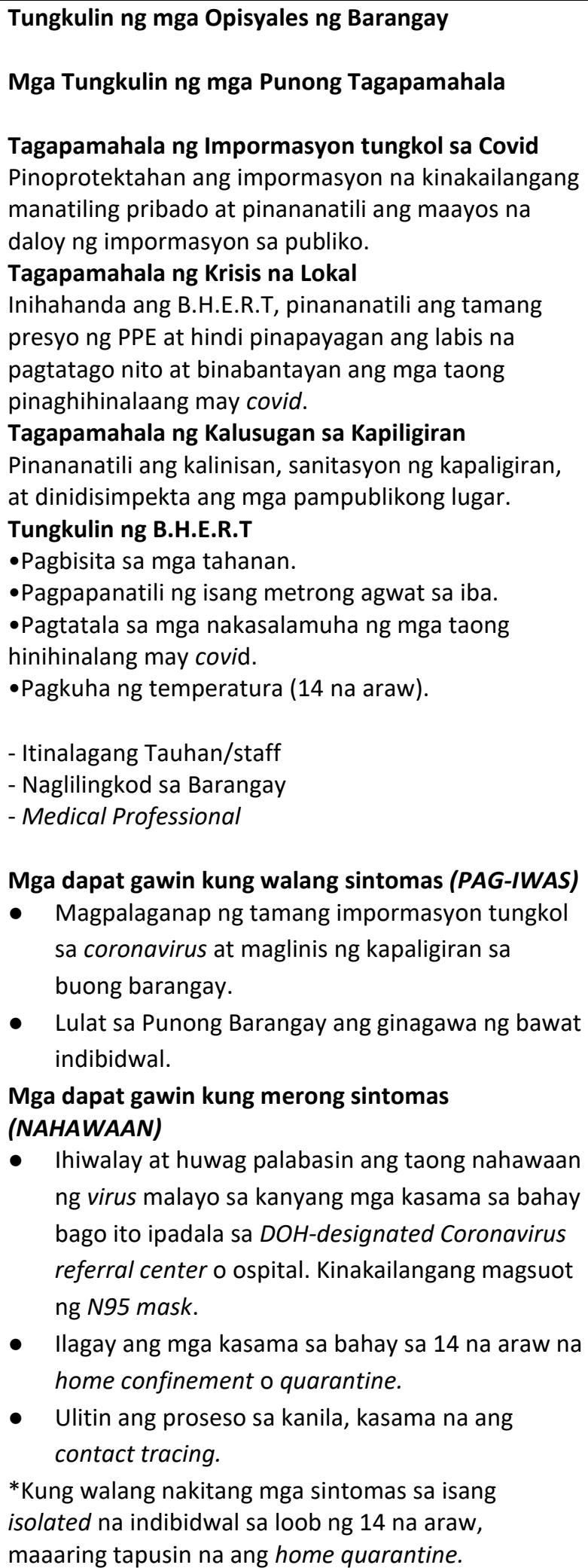 \\
\hline
\end{tabular}

\section{Topic 4. Self-care Management}




\begin{tabular}{|c|c|}
\hline Deverbalization & Transcoding \\
\hline $\begin{array}{l}3 \text { R's in the New Normal } \\
\text { Reduce - avoid impulsive buying or hoarding } \\
\text { Reuse - avoid repeating or personal materials and } \\
\text { choose quality bound } \\
\text { Recycle - avoid recycling products with possible } \\
\text { contamination } \\
\text { Practice Physical Distancing } \\
\text {-panatilihin ang isang metrong layo sa kausap } \\
\text {-umiwas sa mataong lugar } \\
\text { Do hand hygiene } \\
\text {-soap, water } \\
\text {-alcohol/sanitizer } \\
\text {-antiseptic wipes } \\
\text { Tandaan } \\
\text { K-augalian lumayo ng dalawang metro } \\
\text { A-lamin ang dalawang metrong layo } \\
\text { L-lumabas kung kinakailangan } \\
\text { A-alalahanin ang wastong paghuhugas ng kamay } \\
\text { T-andaan ang paggamit ng sabon at tubig sa } \\
\text { paghuhugas }\end{array}$ & 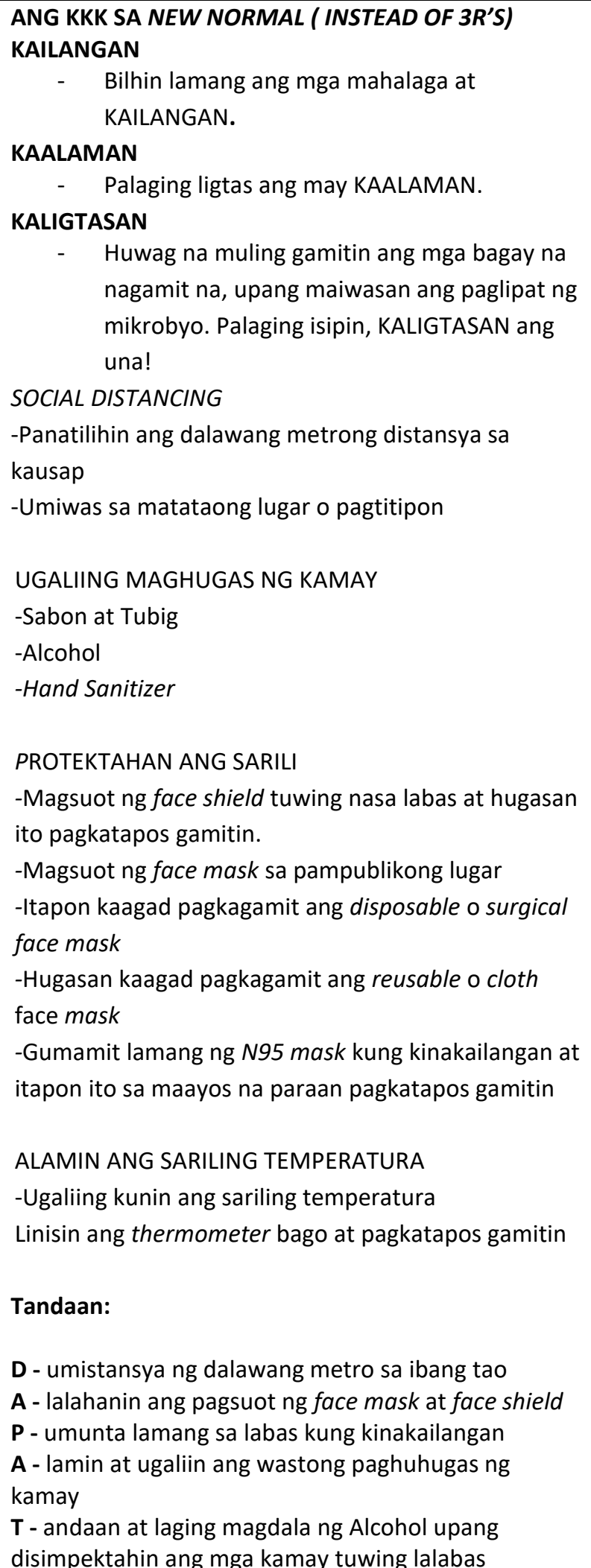 \\
\hline
\end{tabular}


Presented below are the actual communicative materials created. It is important to note that further revisions from the transcoding were still incorporated for the overall improvement of the infographics. The SPU Manila SCBPMM team opted to retain English terminologies that are easy to understand. They also dictated technical standards for the infographics, such as colors, icons, and the like; however, this study was more concerned in the general standards of what makes communication materials understandable as dictated by WHO's Strategic Communication Framework (2017). Accordingly, communication materials must use "clear and plain language to explain global and health issues." The text in the infographics presented below are short and direct. Comparison was also used to explain the virus, its symptoms, while a relatively new concept, contact tracing, was fully discussed as well by using WH-questions. Secondly, these materials must tell "stories with a human dimension to make the issues real to those at work." Although the communication materials may not exactly tell stories, the idea that ITT is a communicative approach has set an amiable tone in presenting the information, as if the infographics are speaking to its audience directly. The translators also tried to make the language more positive my transforming the acronym K.A.L.A.T (kalat is a Filipino term which means trash) into D.A.P.A.T (dapat is a Filipino term which means must). Moreover, since the communication materials are in infographics format, icons were used to explain concepts, while numbers and graphics were used to illustrate process. According to WHO, "incorporating visual components that show and enhance [their] content" adds to understanding. Finally, the materials are in Filipino, which is an effort to communicate in multiple languages.

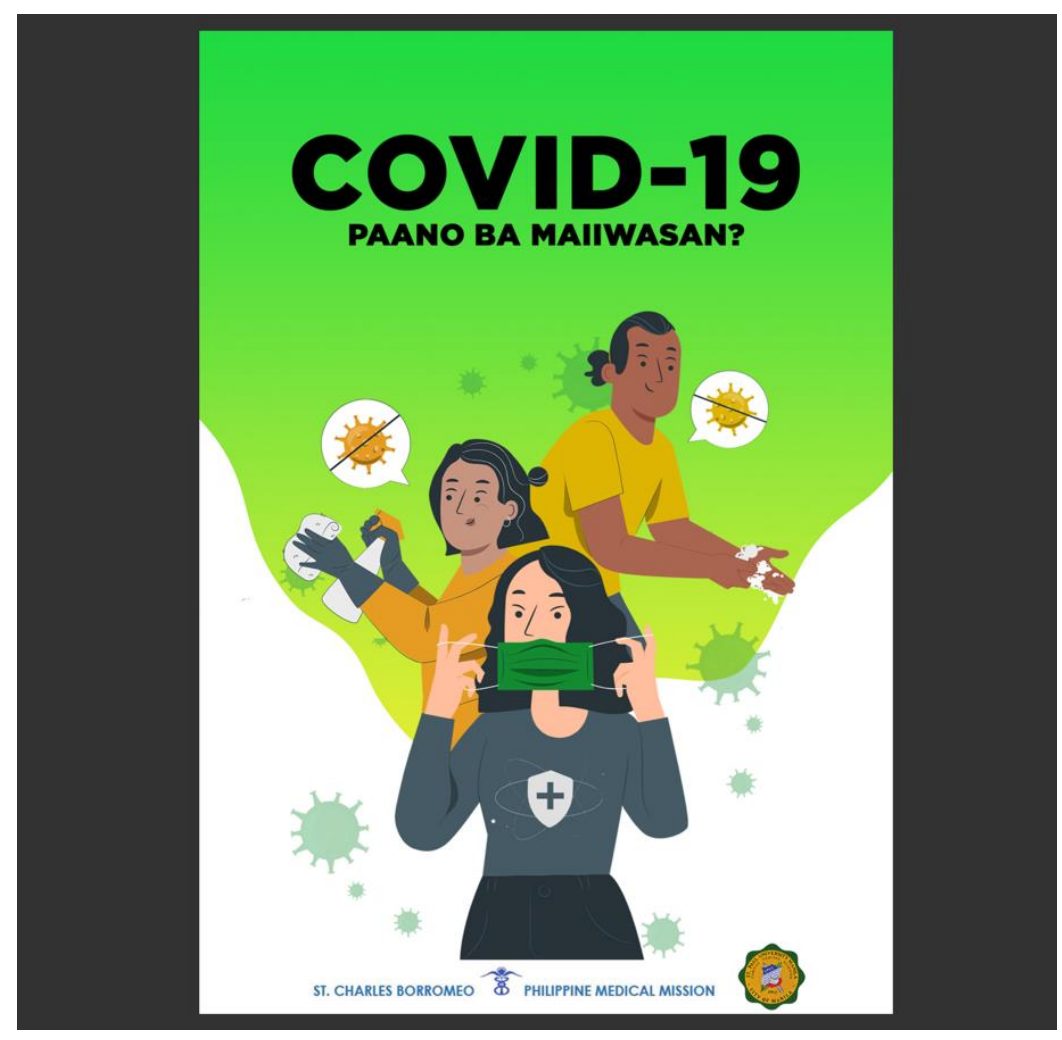



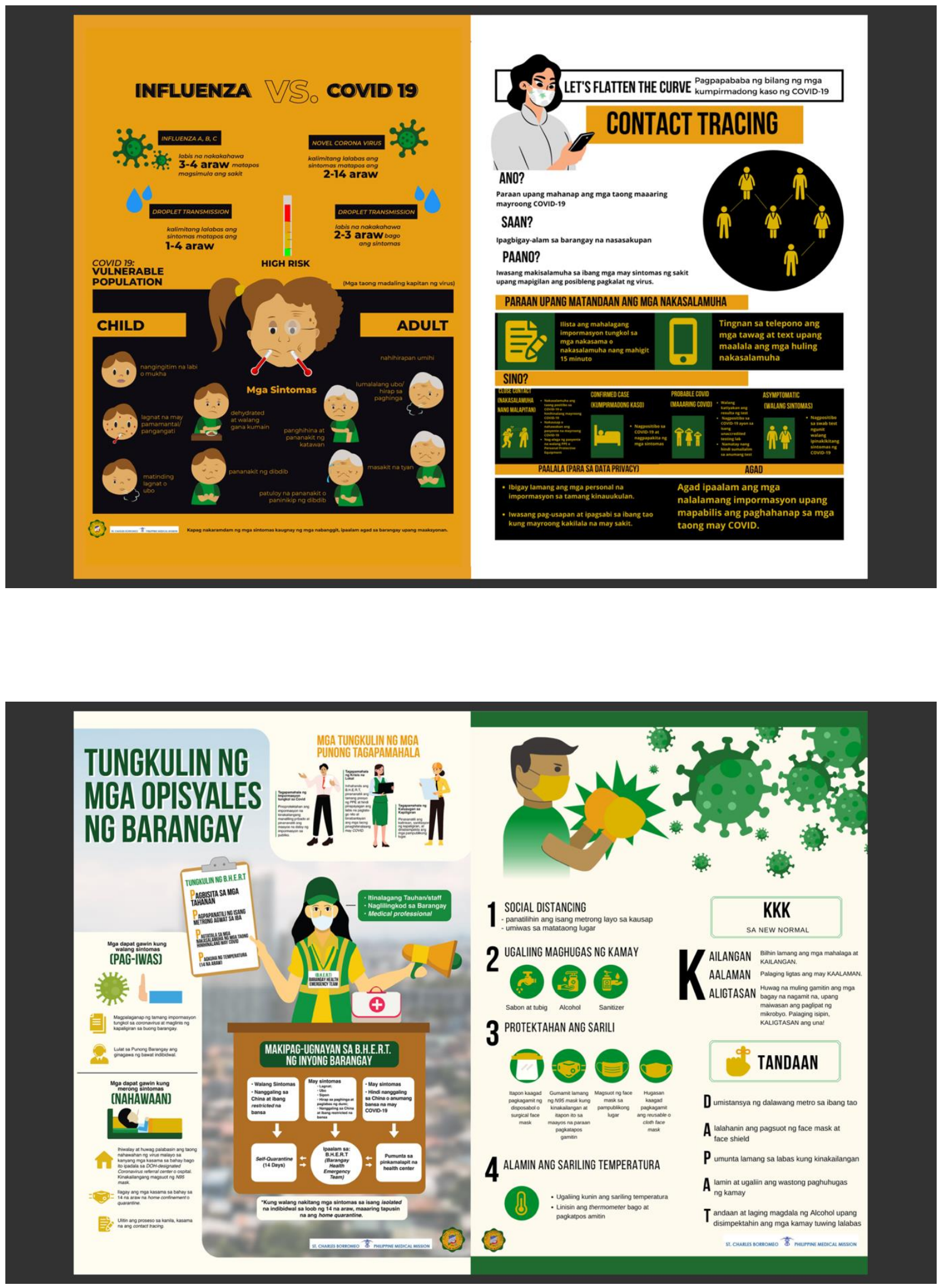

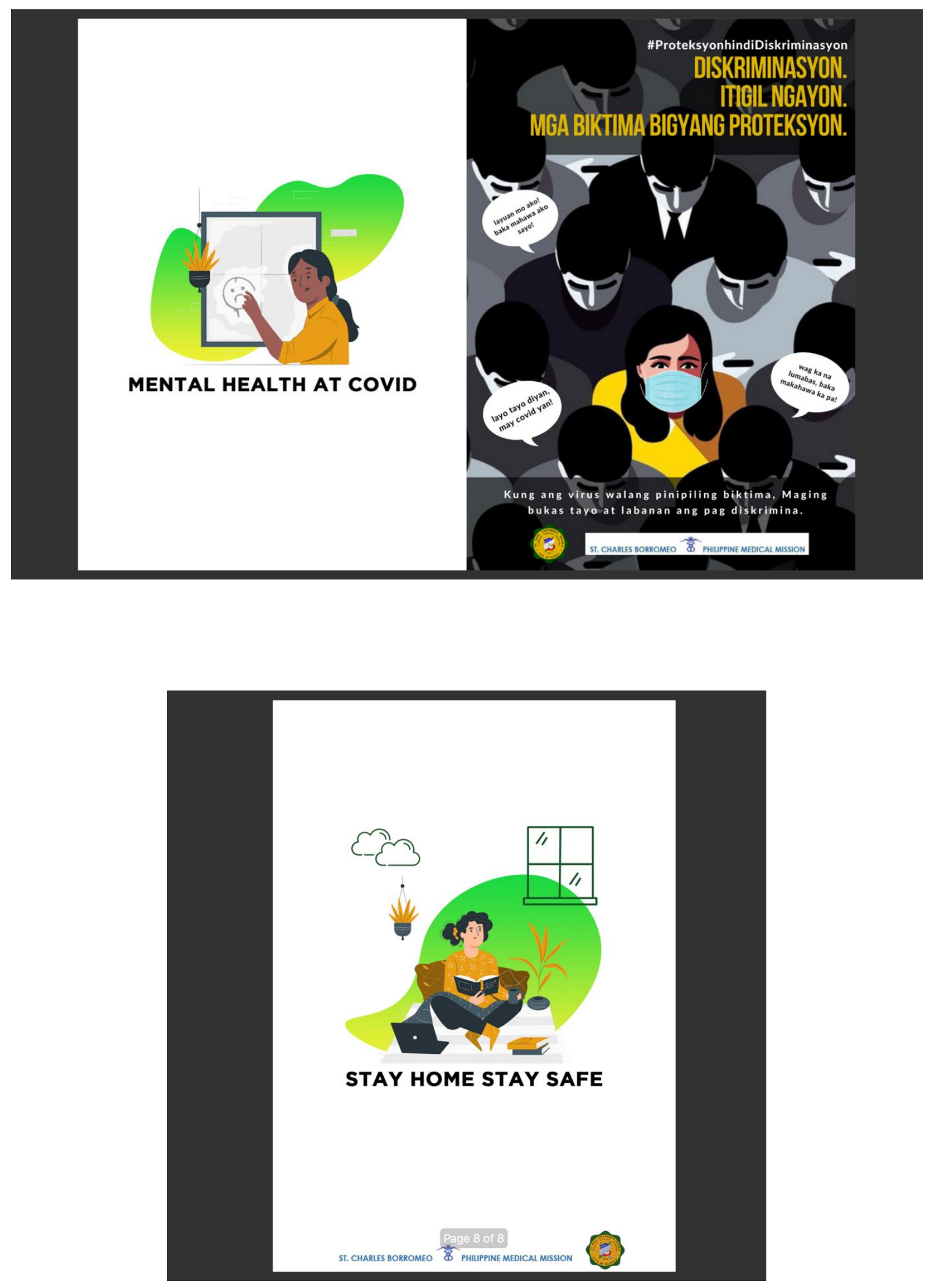

\section{CONCLUSION}


This study was conceived because of the challenge posed by the COVID-19 pandemic in the area of Applied Linguistics. The review of literature prove that language and linguistic studies are an essential in a global emergency, such as a pandemic. This translation study aimed to create Covid-19 health protocol communication materials in Filipino to cater to a general audience. Adopting the Interpretive Theory of Translation (ITT) by Danica Seleskovitch and the sixth element (understandable) of the WHO Strategic Communications Framework for Effective Communication (2017), the study developed the Translating and Creating Communications Material Framework to guide the research process. With this, the study was involved in synthesizing gathered information on COVID-19 health protocols which are in the source language, English. The translation itself involved deverbalizing and transcoding, where making sense of the information was done before they were completely translated to the target language, Filipino. Since the main aim is to communicate understandable information, the communication materials are in infographics form. Some English terms were also retained as they are easier to comprehend by the general audience who are households in selected communities. As envisioned by the SCBPMM, this study recommends further developing COVID-19 health protocols in audio-visual format using the Filipino language. In the linguistic aspect, the provincial government and private sectors may also continue this effort of knowledge empowerment and information dissemination using the different languages in the Philippines. In the communicative aspect, it is recommended to continue the update of information, especially since the pandemic is not yet over. Information and communication materials about the vaccine, for example, may be created to ease the fear and doubt of many Filipinos towards it. Lastly, information on mental health amidst Covid19 may also be explored. Although, this topic was discussed in this collaborative project, information was more focused on the stigma in the virus. On this note, information on some coping mechanics in different contexts may be discussed.

\section{REFERENCES}

Augustyn, R. \& Prazmo, E. (2020). The Spread of Chinese Virus in the Internet Discourse: A Cognitive Semantic Analysis. GEMA Online Journal of Language Studies, 20(4), 209-227. https://doi.org/10/17576/gema-2020-2004-12

Benjamin, J. (2015). Handbook of Translation Studies Volume 1. Philadelphia, USA: John Benjamins Publishing Company.

Catelli, R. et al. (2020). Crosslingual named entity recognition for clinical re-identification applied to a Covid-19 Italian data set. Applied Soft Computing, 97, N.PAG. https://doi.org/10.1016/j.asoc.2020.106779

Cultures Connection. (2020). 6 Contemporary Theories toTranslation. Available at: https://culturesconnection.com/6-contemporary-theories-to-translation/

Jungwha, C. (2013). The Interpretive Theory of Translation and its Current Applications. Available at: http://jaits.jpn.org/home/kaishi2003/pdf/01-choi_final_.pdf 
Kang, Q. (2013). Application of the interpretive theory of translation in interpreting practice. Canadian Social Science 9(6). Doi: 10.3968/j.css.1923669720130906.2903

Komisyon ng Wikang Filipino. (2020). Paliwanag sa tema ng Buwan ng Wika 2020. Available at: https://pia.gov.ph/features/articles/1049346

Mesthrie, R. (2020). More eyes on Covid-19: Perspectives from Linguistics: Pay attention to how people are talking about the pandemic in different languages. South African Journal of Science, 116(7/8), 9. https://doi.org/10.17159/sajs.2020/8497

Moon, H. \& Lee, G. H. (2020). Evaluation of Korean-Language Covid-19-Related Medical Information on YouTube: Cross-Sectional Entomology Study. Journal of Medical Internet Research, 22(8), N.PAG, https://doi.org/10.2196/20775

Olimat, S. N. (2020). Covid-19 Pandemic: Euphemism and Dysphemism in Jordanian Arabic. GEMA Online Journal of Language Studies, 20(3), 268-290. https://doi.org/10/17576/gema-2020-2003-16

Opsahl, W. (2012). Knowledge Translation Practices of Health Services Research Organizations in the United States.

Reality Check Team. (2020 April). Coronavirus: Trump's disinfectant and sunlight claims fact-checked. BBC News. Available at: https://www.bbc.com/news/world-us-canada52399464

\section{$\underline{\text { AUTHORS' BIO }}$}

Claudine Mariano Alhambra, MALED is a faculty member at St. Paul University Manila, where she is also the Chairperson of the Communications and English Program. She is currently taking up her doctorate degree in Applied Linguistics at Philippine Normal University Manila.

Eva Navarro, LPT is the Chairperson of the Teacher Education Program of St. Paul University Manila. She has been a Filipino teacher for several years, and she is also a Filipino expert who does translations in business communication. 